\title{
Seasonal distribution of American plaice on the northern Grand Banks
}

\author{
M. J. Morgan, W. B. Brodie \\ Science Branch, Dept. of Fisheries and Oceans, PO Box 5667, St. John's, Newioundland, Canada A1C 5X1
}

\begin{abstract}
In 1985 seasonal surveys were conducted on the northern Grand Banks in NAFO Division $3 \mathrm{~L}$ to determine if there was seasonal variation in the distribution of American plaice Hippoglossoides platessoides Fabricius. Plaice were generally most common between 100 and $200 \mathrm{~m}$ depth but were more abundant in depths $<100 \mathrm{~m}$ in spring than in other seasons. Fish were under-represented at temperatures greater than $+1.0^{\circ} \mathrm{C}$ in all seasons but were much more under-represented at temperatures of $-1.2^{\circ} \mathrm{C}$ and less, in depths of less than $150 \mathrm{~m}$ in winter than in other seasons. There was significant seasonal variation in the geographic distribution of American plaice with the fish being more aggregated in winter than in other seasons. This aggregation was adjacent to an area covered by water of $-1.2^{\circ} \mathrm{C}$ and less, where few fish were present, and may be related to a greater avoidance of cold water by the fish in winter than in other seasons.
\end{abstract}

\section{INTRODUCTION}

American plaice Hippoglossoides platessoides Fabricius is a very important commercial groundfish species and is probably the most abundant flatfish in the northwest Atlantic. It has a wide geographic distribution in this area, occurring from western Greenland to the Gulf of Maine. The area of highest abundance of American plaice is the northern half of the Grand Banks, where it inhabits waters primarily at depths of 125 to $200 \mathrm{~m}$ and temperatures of -0.5 to $+1.0^{\circ} \mathrm{C}$ (Scott \& Scott 1988). Pitt (1975) reported that plaice in this area are usually fished commercially at depths between 73 and $183 \mathrm{~m}$.

Although the general distribution of American plaice is well known, there is little information on the specific details of this distribution. In particular, it is not known whether the distribution of plaice on the Grand Banks exhibits any seasonal variation. American plaice in the Gulf of St. Lawrence, as well as other species of flatfish, are known to undergo seasonal movements (Powles 1965, Bowering 1976, Scott \& Scott 1988, Metcalfe et al. 1990) and there are a number of factors which change seasonally on the Grand Banks which could result in a seasonal shift in the distribution of plaice. Most species have a limited range of temperatures within which they most frequently occur and many actively attempt to stay within this range (Bond 1979). Temperature varies seasonally on the Grand Banks and plaice may alter their distribution to remain within their preferred temperature range (Wells et al. 1988). The location and abundance of preferred prey items also affects the distribution of fishes and can vary with season. Some fishes shift their distribution with their yearly reproductive cycle, forming spawning concentrations or dispersing to establish territories (Bond 1979, Turner 1986).

The purpose of this study was to determine if there is seasonal variation in the distribution of American plaice on the northern Grand Banks and to investigate possible causes of any differences found.

\section{MATERIALS AND METHODS}

In 1985, surveys for all 4 seasons were conducted on the northern Grand Banks in Northwest Atlantic Fisheries Organization (NAFO) Division 3L (Figs. 1 \& 2). The surveys were carried out onboard the research vessel 'Wilfred Templeman', a stern trawler of $925 \mathrm{t}$ gross tonnage and $50 \mathrm{~m}$ overall length. The net used was an Engels 145 bottom otter trawl, fitted with a small $(29 \mathrm{~mm})$ mesh liner in the codend to prevent 


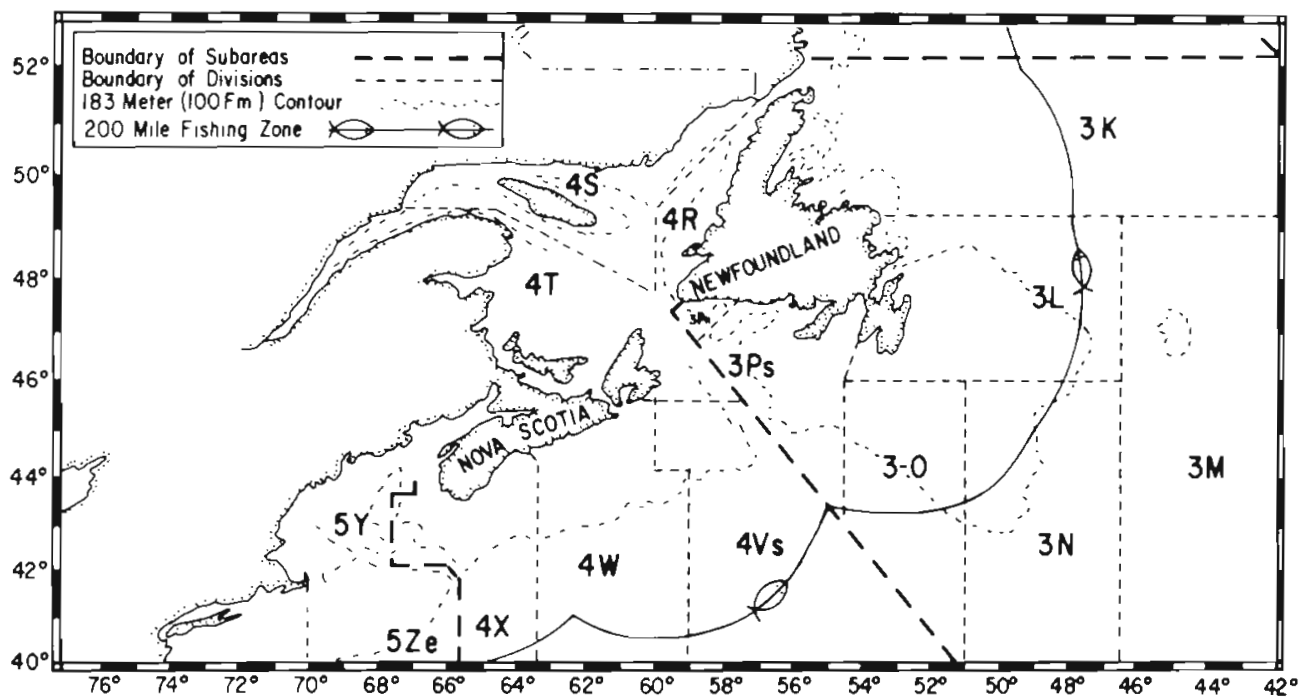

Fig. 1. Southern part of area of distribution of American plaice in the Northwest Atlantic and position of study area,

NAFO Division $3 \mathrm{~L}$

escape of small fish. Fishing sets were completed in bottom depths from 62 to $710 \mathrm{~m}$, using a stratified random survey design with the depth stratification described in Doubleday (1981) (Fig. 2). A set consisted of towing the net over the bottom at a speed of 3.5 knots for $30 \mathrm{~min}$. For each survey, sets in the depth strata were chosen at random, with the number of sets being approximately proportional to the stratum area. A further stipulation was that there be at least 2 sets in each stratum. This was achieved in all but a few cases over the course of the 4 surveys. Each survey was conducted over a period of about $6 \mathrm{wk}$, with the winter survey being done in January-February, spring survey in April-May, summer in July-August and the fall survey in October-November. A total of 810 sets were completed with 182 in winter, 221 in spring, 175 in summer and 232 in fall. These numbers include only the sets with minimal or no net damage. Catches from the few sets which covered less than the standard $1.75 \mathrm{n}$ miles were adjusted to correspond to the norm.

From each set, the weight and number of American plaice were recorded. Usually, the entire catch of American plaice was examined to determine sex, with subsamples taken for determination of stomach contents and stage of maturity. Males were considered to be in spawning condition if some milt had been extruded but residual milt was evident in the testes, or if spawning had been completed and recovery had not yet begun. Females were considered to be in spawning condition if some eggs had been extruded but some

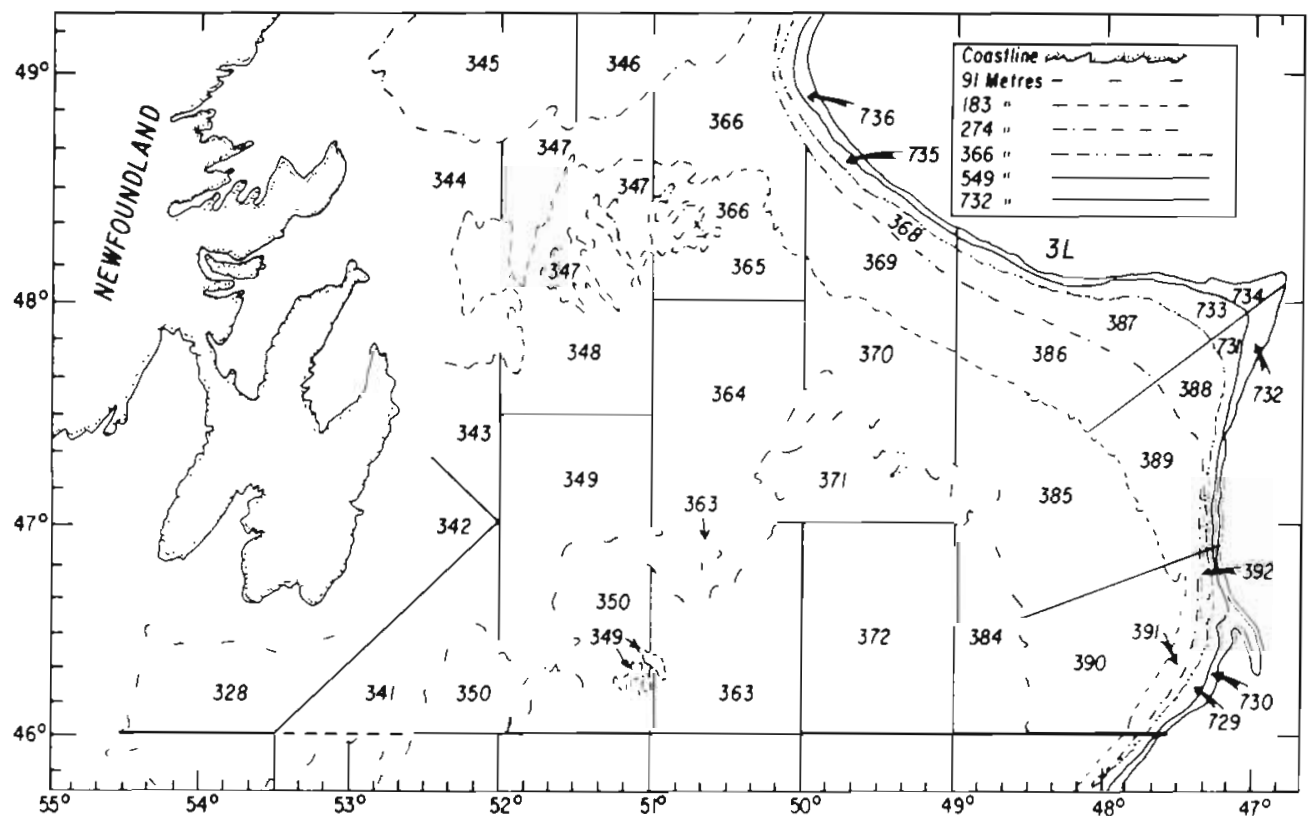

Fig. 2. Study area (NAFO Division 3L) showing the depth contours of the area and the stratification scheme used in conducting the seasonal surveys 
free-running clear eggs remained in the ovaries, or if spawning had been completed and there was no evidence of recovery. Bottom temperature was recorded at the end of each set, usually by expendable bathythermograph (XBT) and the depth fished was noted during each set from the ship's sonar.

Two-way ANOVA by ranks (Zar 1984) were performed to determine if there were seasonal differences in the number and weight of fish caught at different geographic areas. Since different numbers and weights of fish were caught each season, the proportion of a season's total number or weight caught in a given set was used in the ANOVAs. As a descriptor of geographic area, the study area was divided into squares of $1^{\circ}$ of longitude by $1^{\circ}$ of latitude. Temperatures and depths were grouped into ranges to decrease the number of categories (Table 1). Narrower groupings were used for temperatures less than $0^{\circ} \mathrm{C}$ because these were the temperatures most commonly found. Log-likelihood ratio tests (Zar 1984) were done for each season comparing the distribution of the number of fish caught in each depth and temperature category with the expected distribution if the fish had been caught in proportion to the number of sets completed in each category. Occurrence indices, lobserved number expected number)/expected number, were also calculated for the number of American plaice caught in each depth and temperature category where the expected number assumed that the fish distribution was proportional to the number of sets completed in each depth and temperature range (Rose \& Leggett 1989). If the occurrence index was positive the fish were considered to be over-represented in that category; if negative, they were considered to be under-represented. Contour maps of the weight of fish caught in each season were produced using a computer graphics

Table 1. Groupings of temperatures (T) and depths (D) used in analyses

\begin{tabular}{|cc|}
\hline Range & Category \\
\hline Temperature & \\
$\mathrm{T}<-1.1^{\circ} \mathrm{C}$ & -1.20 \\
$-1.1 \leq \mathrm{T}<-0.5^{\circ} \mathrm{C}$ & -0.75 \\
$-0.5 \leq \mathrm{T}<0.0^{\circ} \mathrm{C}$ & -0.25 \\
$0.0 \leq \mathrm{T}<+1.0^{\circ} \mathrm{C}$ & +0.50 \\
$+1.0 \leq \mathrm{T}<+2.0^{\circ} \mathrm{C}$ & +1.50 \\
$+2.0^{\circ} \mathrm{C} \leq \mathrm{T}$ & +3.00 \\
Depth & \\
$\mathrm{D}<100 \mathrm{~m}$ & 50 \\
$100 \leq \mathrm{D}<150 \mathrm{~m}$ & 125 \\
$150 \leq \mathrm{D}<200 \mathrm{~m}$ & 175 \\
$200 \leq \mathrm{D}<250 \mathrm{~m}$ & 225 \\
$250 \leq \mathrm{D}<300 \mathrm{~m}$ & 275 \\
$300 \mathrm{~m} \leq \mathrm{D}$ & 400 \\
\hline
\end{tabular}

package which defines a 3-dimensional surface (latitude, longitude, weight caught per standard tow) based on Delaunay triangles (G. Black, Dept. of Fisheries and Oceans, Halifax, pers. comm.). For further information on the contouring algorithm see Watson (1982) and Watson \& Philip (1985). Log-likelihood ratios were used to compare the frequency of maturity indices and stomach fulness indices in different areas.

\section{RESULTS}

ANOVA by ranks showed that there was a significant interaction between geographic area and season for the number $(H=94.2, \mathrm{df}=64, \mathrm{p}<0.001)$ and weight $(H=110.7, \mathrm{df}=64, \mathrm{p}<0.001)$ of fish caught. These results indicate a significant geographic shift in the distribution of plaice with season. Contour maps of the weight of fish caught (Fig. 3) show that in winter there was a large concentration of plaice on the northern part of the bank between ca $51^{\circ}$ and $50^{\circ} \mathrm{W}$ and $47^{\circ}$ and $48^{\circ} 30^{\prime} \mathrm{N}$ adjacent to a large area where no fish were caught. In spring, there were some areas where fish were more concentrated than others but these were much smaller than the area of concentration in winter. When compared to winter, plaice were fairly evenly distributed across the bank in spring. Summer showed a similar pattern to spring, with plaice more or less evenly distributed across the area. In fall, the distribution of plaice was not as even with a number of concentrated areas separated by areas of lower catches. Fall was intermediate between summer and winter in the amount of aggregation of the fish. Overall, in 1985, plaice seemed most heavily concentrated in winter, becoming more evenly distributed in spring and summer and becoming somewhat more concentrated again in fall.

The concentration of plaice in winter was not related to spawning or feeding. Only $4.7 \%$ of the total number of males and $0.1 \%$ of the total number of females (one fish) collected in winter were in spawning condition while $64.4 \%$ of males and $26.7 \%$ of females were in spawning condition in spring samples. When only mature fish were included, $5.8 \%$ of males and $0.2 \%$ of females were in spawning condition in winter samples, while in spring, $76.0 \%$ of males and $43.9 \%$ of females were in spawning condition. Log-likelihood ratio analyses showed that females in the winter area of concentration had a significantly different frequency distribution of maturity stages $(G=16.4, \mathrm{df}=2, \mathrm{p}<0.001)$ than females collected from the rest of the study area in winter. There were more immature females in the samples collected from the area of highest concentration than in the rest of the area. This indicates that the fish were not aggregated in a prespawning concen- 


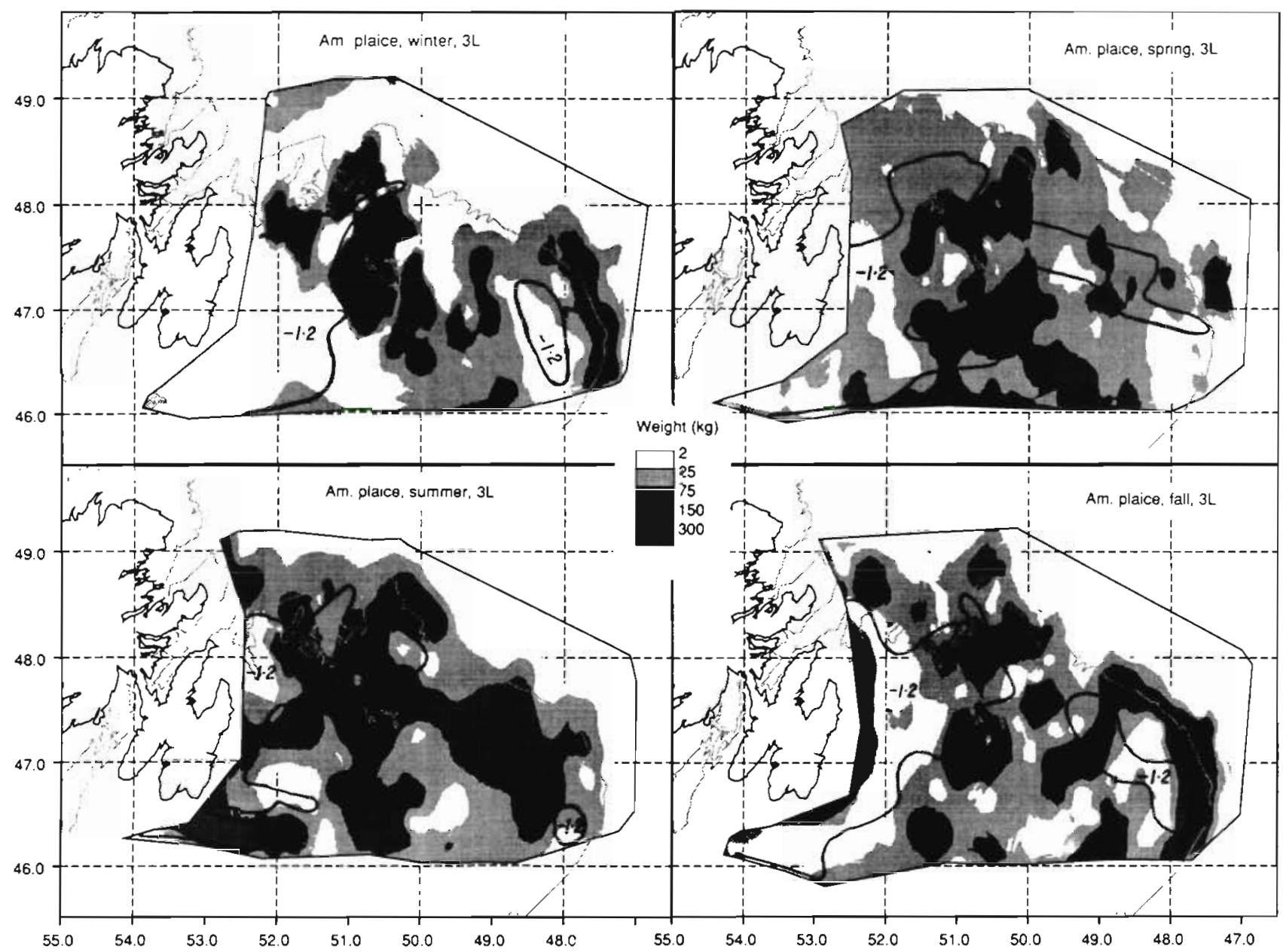

Fig. 3. Contour maps showing the geographic distribution of weight of American plaice catch in the surveys for the different seasons. Weight is contoured based on the total weight of catch in the area swept by a standard tow, $44466.5 \mathrm{~m}^{2}$. The darker the shading the larger the total catch by weight in the area. See key. Also shown are the $-1.2^{\circ} \mathrm{C}$ temperature contours

tration. Examination of stomach fullness data showed that $91 \%$ of all fish collected in the winter had empty stomachs and $100 \%$ of those fish collected from the largest area of concentration in the winter had empty stomachs. The fish were, therefore, not aggregating to feed.

Since temperature and depth are correlated, they were examined together. In all seasons the distribution of the fish across depth/temperature categories was significantly different from the distribution proportional to sampling effort in these categories (winter: $G=30298.3, \mathrm{df}=19, \mathrm{p}<0.001 ;$ spring: $G=4629.6$, $\mathrm{df}=21, \mathrm{p}<0.001 ;$ summer: $G=6325.2, \mathrm{df}=22$, $\mathrm{p}<0.001$; fall: $G=28966.5$, df $=23, \mathrm{p}<0.001)$. In general, the fish were most common at depths from 100 to $200 \mathrm{~m}$ and at temperatures from -1.1 to $-0.5^{\circ} \mathrm{C}$ (Table 2). In all seasons, the fish were under-represented at temperatures above $1^{\circ} \mathrm{C}$ and at depths greater than $300 \mathrm{~m}$. Some seasonal patterns can also be discerned from the occurrence indices. In fall and winter the fish were under-represented at all temperatures in depths less than $100 \mathrm{~m}$. In spring, however, the fish were distributed in proportion to the sampling effort in the $-0.75^{\circ} \mathrm{C}$ category at this depth and over-represented in the $-0.25^{\circ} \mathrm{C}$ category. This may represent a movement into shallower water in the spring. In winter, fish were more under-represented at temperatures of less than $-1.2^{\circ} \mathrm{C}$ in waters less than $150 \mathrm{~m}$, than in other seasons. By summer the fish were not under-represented in these categories. The distribution maps (Fig. 3) show that, in the winter, there were large areas of the bank covered in water of $-1.2^{\circ} \mathrm{C}$ or less, where few or no fish were found. In spring and summer, large areas of this water temperature contained many fish.

\section{DISCUSSION}

The 1985 seasonal surveys showed that American plaice on the northern Grand Banks were nonrandomly 
Table 2. Occurrence indices and number of sets for number of American plaice caught in each temperature and depth category, for each season. Depth and temperature categories are as in Table 1. Indices are (observed number caught - expected)/expected. Expected number assumes that the catch will be proportional to the number of sets in that temperature and depth category. Sample size for each season does not always match the number of sets in that season because of missing temperature data See text

\begin{tabular}{|c|c|c|c|c|c|c|c|}
\hline & \multirow{2}{*}{$\begin{array}{l}\text { Depth } \\
\text { category }\end{array}$} & \multicolumn{6}{|c|}{ Temperature category } \\
\hline & & $-1.2^{\circ} \mathrm{C}$ & $-0.75^{\circ} \mathrm{C}$ & $-0.25^{\circ} \mathrm{C}$ & $0.5^{\circ} \mathrm{C}$ & $1.5^{\circ} \mathrm{C}$ & $3^{\circ} \mathrm{C}$ \\
\hline \multirow[t]{6}{*}{ Winter } & $50 \mathrm{~m}$ & $-0.84(9)$ & $-0.10(19)$ & $-0.18(10)$ & $-0.50(2)$ & - & - \\
\hline & $125 \mathrm{~m}$ & $-0.58(34)$ & +3.54 & - & - & - & - \\
\hline & $175 \mathrm{~m}$ & $+1.19(16)$ & $+2.10(18)$ & $-0.80(2)$ & $-0.56(1)$ & - & - \\
\hline & $225 \mathrm{~m}$ & - & $-0.96(4)$ & $-0.11(6)$ & $+0.19(7)$ & $-0.71(2)$ & - \\
\hline & $275 \mathrm{~m}$ & - & - & -0.85 & $+0.52(1)$ & $-0.50(7)$ & $-0.81(2)$ \\
\hline & $400 \mathrm{~m}$ & - & - & - & - & $-0.56(3)$ & $-0.94(22)$ \\
\hline \multirow[t]{6}{*}{ Spring } & $50 \mathrm{~m}$ & $-0.30(9)$ & $+0.03(21)$ & $+0.76(11)$ & $-0.13(5)$ & $-0.13(2)$ & - \\
\hline & $125 \mathrm{~m}$ & $+0.24(56)$ & $+0.25(10)$ & - & - & - & - \\
\hline & $175 \mathrm{~m}$ & $-0.01(15)$ & $+0.45(16)$ & $+0.20(6)$ & $-0.34(3)$ & - & - \\
\hline & $225 \mathrm{~m}$ & $-0.26(2)$ & $-0.27(9)$ & $-0.49(3)$ & $-0.61(7)$ & $-0.85(3)$ & $-0.66(1)$ \\
\hline & $275 \mathrm{~m}$ & - & - & - & $+0.42(2)$ & $-0.61(8)$ & - \\
\hline & $400 \mathrm{~m}$ & - & - & - & $-0.65(1)$ & $-0.63(7)$ & $-0.37(20)$ \\
\hline \multirow[t]{6}{*}{ Summer } & $50 \mathrm{~m}$ & $-0.02(1)$ & $+0.29(7)$ & $-0.17(13)$ & $-0.60(15)$ & $-0.65(1)$ & - \\
\hline & $125 \mathrm{~m}$ & $+0.45(17)$ & $+0.98(20)$ & - & - & $-0.04(1)$ & - \\
\hline & $175 \mathrm{~m}$ & $-0.26(10)$ & $+0.64(21)$ & $+0.51(3)$ & $-0.44(2)$ & - & - \\
\hline & $225 \mathrm{~m}$ & $+0.57(1)$ & $-0.53(2)$ & $-0.49(3)$ & $+0.07(4)$ & - & - \\
\hline & $275 \mathrm{~m}$ & - & $+2.5 \quad(1)$ & - & $-0.91(5)$ & -0.88 & $-0.78(1)$ \\
\hline & $400 \mathrm{~m}$ & - & - & - & -1.0 & $-0.81(7)$ & $-0.98(17)$ \\
\hline \multirow[t]{6}{*}{ Fall } & $50 \mathrm{~m}$ & $-0.23(7)$ & $-0.20(14)$ & $-0.27(8)$ & $-0.52(26)$ & $-0.52(1)$ & - \\
\hline & $125 \mathrm{~m}$ & $-0.19(40)$ & $+0.55(15)$ & - & - & $-0.87(1)$ & - \\
\hline & $175 \mathrm{~m}$ & $+2.5 \quad(20)$ & $+0.03(21)$ & $+0.43(8)$ & - & - & - \\
\hline & $225 \mathrm{~m}$ & -0.95 (1) & $-0.32(8)$ & $+0.16(2)$ & $+0.05(9)$ & $-0.74(3)$ & - \\
\hline & $275 \mathrm{~m}$ & - & $-0.37(1)$ & $+0.39(2)$ & $-0.59(3)$ & $-0.85(3)$ & $-0.88(5)$ \\
\hline & $400 \mathrm{~m}$ & - & - & - & $-0.45(1)$ & $-0.84(10)$ & $-0.99(20)$ \\
\hline
\end{tabular}

distributed with respect to depth and temperature. They also indicated that there was significant seasonal variation in the geographic distribution of plaice.

American plaice in these surveys were most common at depths between 100 and $200 \mathrm{~m}$ which is similar to the depth range of greatest commercial catches in most years (125 to $200 \mathrm{~m}_{\mathrm{i}}$ Scott \& Scott 1988). Walsh \& Brodie (1987) showed that about $70 \%$ of the directed American plaice catch from the commercial fishery in Division 3L in 1985 came from depths less than $185 \mathrm{~m}$. However, the preferred depth range appeared to be extended into shallower waters in the spring with the fish being more common in waters of less than $100 \mathrm{~m}$ in spring than in other seasons. Powles (1965) attributed seasonal variation in the depth of plaice in the Gulf of St. Lawrence to temperature selection. In this study the move to shallower depths occurred mainly at temperatures between -1.1 and $0^{\circ} \mathrm{C}$.

In all seasons in 1985, plaice were under-represented at temperatures above $+1.0^{\circ} \mathrm{C}$ and overall appeared to be most common between temperatures of -1.1 and $-0.5^{\circ} \mathrm{C}$. The temperature selected by fish is related to the temperature which provides the maximum growth rate, growth being usually depressed at the high and low extremes for the range of temperatures that an organism can tolerate (Beitinger \& Magnuson 1979, Coutant 1987). However, the temperature of highest abundance in the field may not correspond directly to the temperature of optimum growth since the distribution of fish is also influenced by a variety of other factors such as prey abundance (Jobling 1981, Rose \& Leggett 1989).

There was significant seasonal variation in the geographic distribution of plaice in 1985. The most striking aspect of this seasonal variation was the large concentration of fish that was present in the winter. Analysis of catch rates from 1956 to 1989 from Canadian commercial trawlers prosecuting a fishery directed towards American plaice on the Grand Banks showed that January and February were the months in which highest catch rates were achieved (Brodie et al. 1990). This supports the observation from the research vessel surveys that American plaice are more aggregated at that time of year. Since it was evident from this study and from previous work (Pitt 1966) that plaice spawn in spring this aggregation of fish was not a spawning concentration. Further, Pitt (1966) stated that no specific spawning ground for this species was recog- 
nized, and that spawning appeared to be widespread. It also does not appear to have been a prespawning concentration since there were more immature females in the concentration than in the rest of the area. The winter aggregation was also not associated with feeding since $100 \%$ of the stomachs examined in this area were empty. This agrees with earlier studies of plaice which found a cessation of feeding in winter (Powles 1965, Pitt 1973). The observations on sexual maturity and stomach contents are also similar to those reported by Walsh \& Brodie (1987) for a large concentration of plaice observed in April 1987 on the northeast slope of the Grand Bank in Divison 3L. These results indicate that non-feeding, non-spawning aggregations of plaice may not be uncommon in the study area.

The area of high abundance in the winter may be related to a greater avoidance of cold water by plaice in the winter. The fish were more under-represented in waters of $-1.2^{\circ} \mathrm{C}$ and less, in depths of less than $150 \mathrm{~m}$, in the winter than in other seasons. The area of concentration was adjacent to an area in which plaice were found in low abundance and which was covered by a cold water mass with a bottom temperature of $-1.2^{\circ} \mathrm{C}$ and less. It appears that the fish may have moved out of this cold area and into an adjacent area of slightly warmer water.

Season can have a major impact on temperatures selected, possibly through seasonal shifts in metabolic rate (Sullivan \& Fisher 1953, Fry \& Hochachka 1970, Barans \& Tubb 1973). Another factor which may affect the reaction of plaice on the Grand Banks to temperature is avoidance of freezing. American plaice have sufficient antifreeze proteins to withstand freezing to $-1.1^{\circ} \mathrm{C}$ and are often captured at temperatures less than this. However, below this temperature the fish would be supercooled and susceptible to freezing if they were to come into contact with ice crystals. Although it is not known whether ice crystals are transported to bottom waters inhabited by plaice, it may be possible during winter months and would be more likely in shallower water (Fletcher et al. in press). It is interesting to note that during winter 1985 the area of lowest abundance of plaice was covered by water of less than $-1.1^{\circ} \mathrm{C}$ and much of this area was less than $100 \mathrm{~m}$

The cold water mass covered a larger than normal area in 1985 (Wells et al. 1988) and this probably affected the specific distribution pattern found. Other fishes have been found to change their distribution from year to year in relation to the position of water bodies of appropriate temperature (Midtun 1965). In years when less of the bank is covered with cold water the position and degree of concentration of plaice would be expected to change. There is some indication that this is the case. The concentration of plaice observed in the winter survey of 1985 appears to have been denser than usual since the commercial fishery in the southern part of Divison $3 \mathrm{~L}$ recorded catch rates in March which were the highest for any month in the 34 yr time series and were about 7 times higher than the mean catch rate for 1985 (Walsh \& Brodie 1987). At this time research surveys of this area under more typical winter conditions do not exist.

Acknowledgements. We thank all ship's crew and technical staff involved in the collection and examination of samples. C. Butt produced the figures. B. Atkinson produced the distribution maps. J. Hoenig. D. Power and W. Warren gave helpful comments on the manuscript and statistics.

\section{LITERATURE CITED}

Barans, C. A., Tubb, R. A. (1973). Temperatures selected seasonally by four fishes from western Lake Erie. J. Fish. Res. Bd Can. 30: 1697-1703

Beitinger, T L., Magnuson, J. J. (1979). Growth rates and temperature selection of bluegill, Lepomis macrochirus. Trans. Am. Fish. Soc. 108: 378-382

Bond, C. E. (1979). Biology of fishes. Saunders College Publ. Philadelphia

Bowering, W R. (1976). Distribution, age and growth, and sexual maturity of witch flounder (Glyptocephalus cynoglossus) in Newfoundland waters. J. Fish. Res. Bd Can. 33: $1564-1584$

Brodie, W. B., Bowering, W. R., Baird, J. W. (1990). An assessment of the American plaice stock in Divison 3LNO. NW Atlant. Fish. Orgn Sci. Coun. Rep. 90/80, Ser. No. N1804

Coutant, C. C. (1987). Thermal preference: when does an asset become a liability? Environ. Biol. Fish. 18: 161-172

Doubleday, W. G. (1981). Manual on groundfish surveys in the Northwest Atlantic. NAFO Sci Coun. Studies, No. 2, $55 \mathrm{p}$.

Fletcher, G. L., Myers, R. A., Akenhead, S., Davies, P. L. (in press). Death from ice contact: how fish avoid it. International Symposium for Operational Fisheries Oceanography. Can. J. Fish. Aquat. Sci., Special Publ.

Fry, F. E. J., Hochachka, P. W. (1970). Fish. In: Whittow, G. C. (ed.) Comparative physiology of thermoregulation. Vol. 1 Invertebrates and nonmammalian vertebrates. Academic Press, New York, p. 79-134

Jobling, M. (1981). Temperature tolerance and final preferendum - rapid methods for the assessment of optimum growth temperatures. J. Fish Biol. 19: 439-4.55

Metcalfe, J. D., Arnold, G. P., Webb, P. W. (1990). The energetics of migration by selective tidal stream transport: an analysis for plaice tracked in the southern North Sea. J. mar biol. Ass. U.K. 70: 149-162

Midttun, L. S. (1965). The relation between temperature conditions and fish distribution in the southeastern Barents Sea. I.C.N.A.F. Spec. Publ. 6: 213-219

Pitt. T. K. (1966). Sexual maturity and spawning of the American plaice, Hippoglossoides platessoides (Fabricius), from Newfoundland and Grand Banks areas. J. Fish. Res. Bd Can. 23: 651-672

Pitt, T K. (1973). Food of American plaice (Hippoglossoides platessoides) from the Grand Bank, Newfoundland. J. Fish. Res. Bd Can. 30: 1261-1273

Pitt, T K. (1975). Changes in abundance and certain biological characteristics of Grand Bank Americ an plaice. Hippoglossoides platessoides. J. Fish. Res. Bd Can. 32: 1383-1398 
Powles, P. M. (1965). Life history and ecology of American plaice Hippoglossoides platessoides (F.) in the Magdalen shallows. J. Fish. Res. Bd Can. 22: 565 -598

Rose, G. A., Leggett, W. C. (1989). Interactive effects of geophysically-forced sea temperatures and prey abundance on mesoscale coastal distributions of a marine predator, Atlantic cod (Gadus morhua). Can. J. Fish. Aquat. Sci. 46: 1904-1913

Scott, W. B., Scott, M. G. (1988). Atlantic fishes of Canada Can. Bull. Fish. Aquat. Sci. 219

Sullivan, C. M., Fisher, K. C. (1953). Seasonal fluctuation in the selected temperature of speckled trout, Salvelinus fontinalis (Mitchill). J. Fish. Res. Bd Can. 10: 187--195

Turner, G. (1986). Teleost mating systems and strategies. In: Pitcher, T. J. (ed.) The behaviour of teleost fishes. Croom Helm, London, p. 253-274

This article was presented by R. L. Haedrich, St. John's, Nfld Canada
Walsh, S. J., Brodie, W. B. (1987). Aspects of American plaice distribution of NAFO Divisions $3 \mathrm{~L}, 3 \mathrm{~N}$, and 30 NW Atlant. Fish. Orgn Sci. Coun. Rep. Doc. 87/47, Ser. No. N1334

Watson, D. F. (1982). ACORD - automatic contouring of raw data. Comp. Geosci. 8: 97-101

Watson, D. F., Philip, G. M. (1985). A refinement of inverse distance weighted interpolation. Geo-Processing 2 315-327

Wells, R., Brodie, W. B., Bishop, C. A., Baird, J. W. (1988) Distribution and abundance of three fish species on the Grand Bank in relation to depth and temperature of the water. NW Atlant. Fish. Orgn Sci. Coun. Rep. Doc. 88/94 Ser. No. N1546

Zar, J. H. (1984). Biostatistical analysis. Prentice-Hall Englewood Cliffs

Manuscript first received: March 14, 1991

Reviewed version accepted: May 30, 1991 